\title{
ペルテス病における大殿筋・中殿筋萎縮の検討
}

鼓ケ浦整肢学園整形外科
片 岡 秀 雄・杉 基 嗣
開 地 逸 朗
山口大学整形外科
河 合 伸 也・城 戸 研 二

\section{Analysis of Atrophy of Gluteal Maximus and Medius in Perthes' Disease}

by

\author{
Hideo Kataoka, Mototsugu Sugi and Itsurou Kaichi \\ Tuzumigaura Handicapped Children's Hospital \\ Yamaguchi, Japan \\ Shinya Kawai and Kenji Kido \\ Department of Orthopedic Surgery, School of Medicine \\ Yamaguchi University
}

\begin{abstract}
Cross-sectional area of the bilateral gluteus maximus and medius was measured in 10 cases with hemilateral Perthes' disease, using CT scans at the level of the anterior superior iliac spine. The period of measurement from the onset of the disease was 2 months to 3 years and 8 months, and the total number of measurements was 32 . The area ratio of the affected / unaffected side was calculated to evaluate the degree of muscle atrophy. We use wheel chairs and abduction braces for non-weight bearing and good containment.

We compared the averages between the two groups ; group 1) non-weight bearing period using wheel chairs, group 2) more than 12 months after the start of walking. A $6.5 \%$ increase was seen in gluteus maximus and $5.5 \%$ increase was seen in gluteus medius. Recovery of muscle atrophy was very slow and it tended to need a very long time. 5 cases showed Trendelenburg's sign during the measurement and in 4 of the 5 cases, the sign disappeared within 4 months. In the 5 cases that showed Trendelenburg's sign, the affected / unaffected area ratio in both gluteus medius and maximus was less than $91 \%$.
\end{abstract}

Key words : Perthes' disease (ペルテス病), muscle atrophy (筋萎縮), Trendelenburg sign (トレン デレンブルグ現象)

\section{は じめに}

ペルテス病ではほとんどの症例において比較的早期 より殿筋の萎縮や Trendelenburg sign が認められる が, 両者の関係は明らかにされていない.今回我々は 片側罹患ペルテス病児の大・中殿筋萎縮を CT を用い 定量化し経時的な変化と跛行との関係を検討したので 報告する，

\section{対象および方法}

対象は 1989 年 12 月から 1993 年 3 月までに当科を 受診した片側䍜患ペルテス病児 10 例とした。男児 7 例, 女览 3 例で, 受診時年齢は 5 才 0 力月ょり 9 才 9 カ月であった。 X線の Catterall 分類は Group III が 8 例, IV が 2 例であった.

以上の症例に対して CT を用い上前腸骨棘レベルで, 
幅 $10 \mathrm{~mm}$ のスライスを行った. CT フィルム上の大殿 筋, 中殿筋の筋縁をトレースし, エプソン社製スキャ ナーGT-8000を用いMacintosh II ciに取り込み, $\mathrm{NIH}$ 画像解析ソフト（Image 1.44）を用い大・中殿 筋の断面積をそれぞれ求め, 筋萎縮の程度を健側に対 する患側の占める割合で表した。

ペルテス病発症より筋面積測定までの期間は 2 カ月 より 3 年 8 力月で, 合計 32 回の測定を行った。筋萎 縮の経時的な回復を比較するため車イス免荷中から CT 計測までの期間を歩行開始, 歩行開始後 4 力月, 9 カ月, 13 カ月を境界とし 5 群に分けた。

\section{結果}

大殿筋の健側比の平均値は車イス免荷中 4 症例で, $83.5 \%$ であった．歩行開始後 4 力月以内は 7 例で 85.1 $\%, 5 \sim 8$ 力月は 6 例で $88.0 \%, 9 \sim 12$ 力月は 5 例 で $86.8 \% ， 13$ 力月以上は 4 例で $90.0 \%$ あった。中 殿筋の健側比の平均值は, 車イス免荷中 $84.5 \%$, 歩行 開始後 4 力月以内で $87.6 \% ， 5 \sim 8$ 力月で $90.3 \% ， 9$ 〜 12 カ月で $86.2 \%, 13$ カ月以上では $90.0 \%$ あった (表 1). 車イス免荷中群と步行開始後 13 力月以上群 で大殿筋健側比の平均值を較べると大殿筋の健側比は $6.5 \%$ の増加があり, 中殿筋でも平均值を較べると 5.5
\%の増加があった。

Trendelenburg 現象は歩行開始後 4 力月以内の調 查で 7 例中 5 例が陽性でそのうち 1 例が歩行開始後 12 カ月まで跛行が持続していた。

中殿筋健側比と Trendelenburg 現象との関係を調 べたところ，陽性群では 78〜91\%，陰性群では 90〜 98\%，大殿筋において陽性群では 75～89\%，陰性群 では 85〜91\%となった。

表 1 大 - 中殿筋断面積の健側比

\begin{tabular}{c|c|c|c|c|c}
\hline \hline & 免荷中 & \multicolumn{4}{|c}{ 歩行開始後 } \\
\cline { 2 - 6 } & & $\leqq 4 \mathrm{M}$ & $5 \sim 8 \mathrm{M}$ & $9 \sim 12 \mathrm{M}$ & $13 \mathrm{M} \leqq$ \\
\hline $\begin{array}{c}\text { 大殿筋 } \\
\text { 範囲 }\end{array}$ & & & & & \\
$\begin{array}{c}\text { 平均 } \\
\text { (\%) }\end{array}$ & $81 \sim 92$ & $75 \sim 91$ & $79 \sim 96$ & $77 \sim 98$ & $81 \sim 97$ \\
& 85.1 & 88.0 & 86.8 & 90.0 \\
\hline $\begin{array}{c}\text { 中殿筋 } \\
\text { 範囲 }\end{array}$ & $73 \sim 90$ & $78 \sim 98$ & $83 \sim 99$ & $76 \sim 96$ & $84 \sim 93$ \\
平均 \\
(\%)
\end{tabular}

\section{中殿筋}

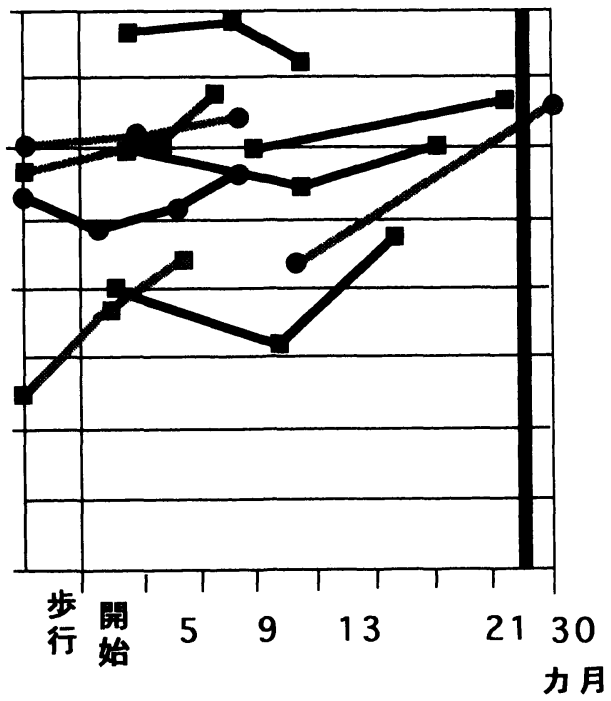

力月

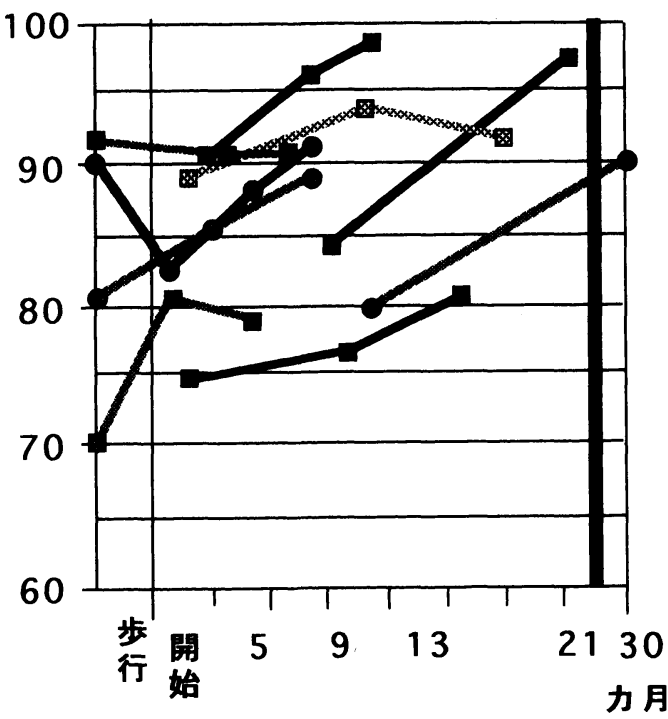

図 1 健側比の変化 
中殿筋

(\%)

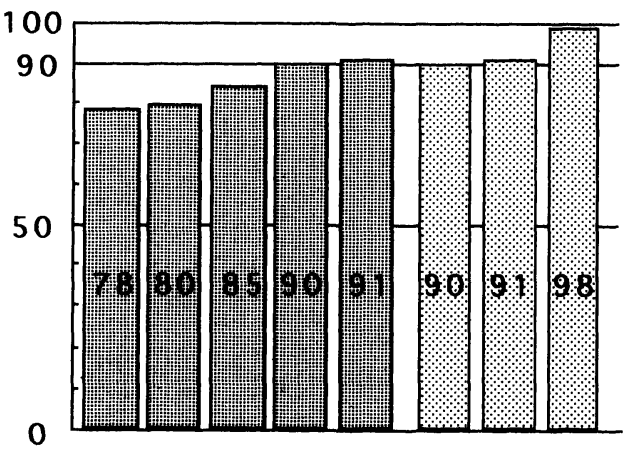

Trendelenburg $(+)$

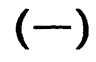

大殿筋

(\%)

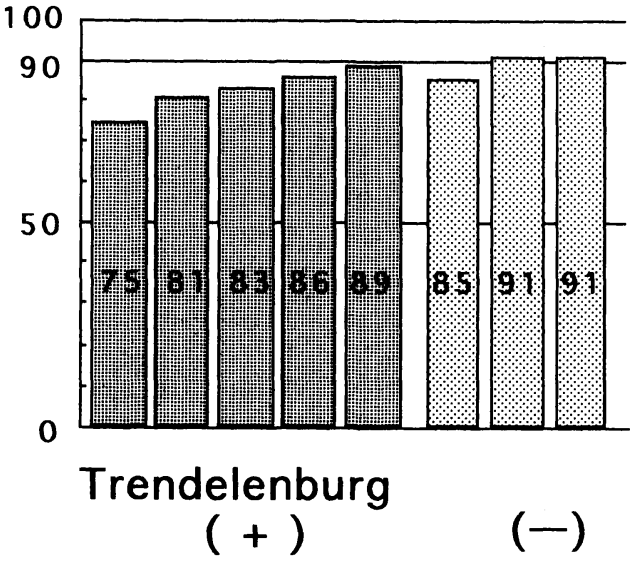

図2 中・大殿筋健側比と跛行

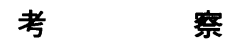

仲宗根ら ${ }^{1)}$ は大・中・小殿筋のうち大殿筋の萎縮度 が最も大きかったと報告している。しかし, 我々の症 例においては全測定例での大殿筋, 中殿筋の平均值は 各々 $86.3 \% ， 87.0 \%$ とっており明らかな差は見られ ず，萎縮はほほ同程度に両筋に及んでいた。

大殿筋の健側比の変化を車イス免荷中から歩行開始 後 13 力月以上まで経時的に見ると個々の症例でばら つきがあるものの長期的には増加傾向が見られた。中 殿筋においても一時的に減少をきたす症例があるもの の長期的には増加傾向が見られた（図 1 ). 当園では ペルテス病初期より車イス免荷と外転装具療法ととも に, 股・膝関節 ROM 訓練, 筋力強化訓練を行い廃用 性筋萎縮の予防に努めているが, 早期からの萎縮が明 らかであり大・中殿筋萎縮の回復には長期を要すと考 えられる。

Trendelenburg 現象陽性を示したのは 5 例で 1 例 を除き 4 力月以内に陰性となっており, 田村 ${ }^{2)}$ の報告 に比して, 早期に消失していた. 初期の筋力増加は中 枢神経系の興奮水準の変化によっておこり筋面積の増 大に先行するとされており ${ }^{3)}$, 前述した如く筋面積の 回復には長期を要するにもかかわらず Trendelenburg signが消失した理由の 1 つと推測さ れた.
筋面積健側比と跛行との関係を中殿筋で見ると歩行 開始後初回測定時に健側比が $91 \%$ を越え Trendelenburg 現象陽性となる症例は見られなかっ た. 大殿筋でも中殿筋同様， $91 \%$ を越え Trendelenburg 現象陽性となる症例は見られなかっ た (図 2 ). LeBlancら ${ }^{4)}$ は下腿三頭筋に平均 $12 \%$ の 筋萎縮が見られ最大 $26 \%$ の筋力低下があったと報告 している. 我々の症例では中・大殿筋とも約 $10 \%$ 以 上の筋萎縮があると Trendelenburg 現象陽性となる 筋力低下が発生するのではないかと推測された。

\section{結語}

1. 片側ペルテス病児 10 例を対象として大・中殿 筋断面積を測定した。

2. 大・中殿筋萎縮の回復は長期を要し徐々に進む 傾向にあった。

3. 中・大殿筋とも筋萎縮の健側比が $90 \%$ 付近に Trendelenburg 現象陽性となる境界が存在すると考 えられた。

\section{参考文 献}

1）仲宗根聡他：ペルテス病における殿筋萎縮の検討. 整 形外科と災害外科, 42 (2) $559-562,1993$.

2）田村 清：ペルテス病. 股関節外科学，255-297。伊 藤鉄夫編, 金芳堂, 1991 . 
3）福永哲夫：ヒトの絶対筋力. 杏林書院，1978。

4) LeBlanc et al. : Calf muscle area and strength changes after five weeks of horizontal bed rest.
American Journal of Sports Medicine, Nov.-Dec. 16 (6) : 624-9, 1988. 